\title{
PHYTONYMS IN REFLECTION OF PEOPLE'S SUPERSTITIOUS TRADITIONS AS AN ASPECT OF LINGUISTIC EDUCATION (BY THE MATERIAL OF GERMAN)
}

\author{
Oksana G. Kuptcova ${ }^{1}$, Anna L. Kolyago ${ }^{2 \star}$, \\ Alla A. Fokina ${ }^{3}$, Elena L. Petrova ${ }^{4}$, Galina L. Sokolova ${ }^{5}$ \\ ${ }^{1}$ As. Prof., Interregional Open Social Institute, Mari State University, RUSSIA, \\ kuptcovaOG@yandex.ru \\ ${ }^{2}$ As. Prof., Mari State University, RUSSIA, kolyago@yandex.ru \\ ${ }^{3}$ As. Prof., Mari State University, RUSSIA, allafokina70@mail.ru \\ ${ }^{4}$ As. Prof., Mari State University, RUSSIA, jandar78@mail.ru \\ ${ }^{5}$ As. Prof., Mari State University, RUSSIA, askgalinasokol@mail.ru \\ ${ }^{*}$ Corresponding Author
}

\begin{abstract}
In foreign and domestic language education, in folkloristics extensive experience has been accumulated in the study of names of medicinal plants both by the material of one language and in a comparative aspect. The issues of comparative research of languages which are studied by contrastive linguistics make it possible to penetrate deeper into the peculiarities of each language than it is possible to study single one. At the same time it becomes possible to identify and describe those features of compared languages that can elude our attention to only internal study of language. However, researches which are conducted by the material of one language or one language family differ in a certain peculiarity and depend on the traditions of the civilization to which this language belongs. The study of traditions, beliefs and everyday life has been on the periphery of linguists' attention for several centuries. The mention of medicinal plants is clearly traced in Pagan and Christian traditions, in economic activity, the healing practice of banners and herbalists, which is directly verbalized in plant names. Phytonyms are considered and classified by linguists, philologists according to certain motivated types of nomination. The concept of "nomination principle (motivema)" is quite widely used in modern dialect lexicology in describing various thematic groups of vocabulary, primarily phytonyms. One of the features of the typological character in phytonymic vocabulary is the variety and numerous principles of the nomination: in color, in use in medicine, etc..

The purpose of this article is a semantic analysis of phytonyms in German, united by the motivema "popular beliefs, superstition". The actual material for the study has been the author's card file, consisting of 53 the most common medicinal plants and including more than 4,000 names (Rubtcova, 2015). The method of synchronous description of the collected material is used to solve the purposes and tasks set in the work, using distributive analysis and elements of the diachronic method. The article clearly demonstrates how centuries-old Pagan and Christian beliefs associated with the holidays, their ritual side, folk magic and demonology have formed the basis of a number of medicinal plants' names.
\end{abstract}

Keywords: phytonym, medicinal plants, belief, legend, magic properties, the German language, motivema, nomination, language education

\section{INTRODUCTION}

Medicinal plants have always been present in the life of any people. Their scope of application is unlimited. They were used in the treatment of diseases of various etiologies, whether they were any somatic diseases or 'sent' by evil spirits, sorcerers, in ritual activities during conspiracies for luck, love, health, wealth. 
Medicinal plants were tied to clothes, believing that grass would save and protect travelers on the road and soldiers in the war. Learning the world around us, people always tried to attribute special otherworldly power to any mysterious incomprehensible phenomenon. Unusual and rare properties of plants could be the impetus for attributing magical properties to them, creating legends, beliefs.

The origin of beliefs about fantastic herbs is associated with man's eternal desire to rise above the nature. Origins of legends and beliefs go back, first of all, to the exaggeration of the properties that a plant possesses. It applies mainly to medicinal flora. Perhaps therefore, for example, the non-flowering plant fern always surprised with its appearance and unusual way of reproduction. All plants bloom, but fern doesn't - it means that the plant is special and is marked by mystery. Thus, so many legends and beliefs arise among people about it. Exactly in them the background dweller of forests is endowed with those properties that man does not actually observe: the fern blooms, it is not simply but magically. On Ivan Kupala's night many people go to the forest in search of a magical flower, which gives the opportunity to gain wealth and learn how to manage the nature. It is known, that it has been one of mankind's cherished desires since the creation of the world.

Our study continues a series of articles on the problem of language education in the German language (Bogdanova, Kolyago, Fokina, Sokolova, Yandakova, 2017), (Sokolova, Kolyago, Fokina, Rychkov, Bogdanova, Trubyanova, Yandakova, 2017)

\section{OPINION AND DISCUSSION}

In the old days witch doctors and herbalists treated with great respect and reverence for the process of collecting herbs, read conspiracies and prayers. The period of collecting medicinal herbs was coincided with Agrafena-Kupalnitsa's day. Immediately after it Ivan Kupala's day followed, it was the time of collecting magic herbs. It was believed that before Ivan Kupala's day herbs' power was in their leaves, and after that day it was followed into roots. It is evidenced by the German phytonym Johanniswurzel to refer fern and Johanniswurz (German das Johannis. religious 'Ivanov's Day'; die Wurzel 'root') - for the nomination hypericum. As Ivan Kupal's day coincides with the day of the summer solstice, the phytonym Sonnenwendkraut (German die Sonnenwende 'solstice'; das Kraut 'grass') (Rubtcova, 2015) is homonymous for plants wormwood and hypericum, it demonstrates their inextricable connection with the holiday. Although it should be noted, that Johanniskraut was its own in each area of Germany, of course, most often it was hypericum. In Thuringia arnica was called Johanniskraut and it was used to prepare ointments (Markina, 2006).

According to superstitious ideas, the most incredible miracles are performed on Ivan Kupala's night. The fern blossoms, games start, Kupala's lights are lit, sorcerers and witches go to the forest for thirlich-grass (centaury) on the night. The legend says that fern allegedly blooms only on Ivan Kupala's night. Similar to wings of an eagle, a flower's bud rises like a luminous corner between the leaves. At midnight the bud opens with a crack, a fiery flower appears, illuminating everything around it. The name Springwurzel (literally 'jumping root', German springen 'jump') (Rubtcova, 2015) is explained by the German belief that on Ivan Kupala's night the fiery flower does not stand in one place, but it jumps. Some people add that thunder is heard and the ground is shaken (Potebnya, 2000).

People believed that fern had mighty ancient force: one, who owned it, was not afraid of thunder, water or fire; all his wishes were immediately fulfilled; he understood the language of flowers and birds, trees and animals. In the German language person's ability to control evil spirits functions in folklore phytonym Teufelsleiter literally. 'master of wickedness (devils)' (German der Teufel 'devil, evil spirit'; der Leiter 'leader') (Rubtcova, 2015). In the phytonym Schnackenkraut (German schnacken "chat, talk, crack (about the magpies)'; das Kraut 'grass') (Rubtcova , 2015) expresses the unique ability of a person to understand birds' language. The process of acquisition and preservation of a magical flower is very difficult, as evil spirits make every effort to take away it. But whoever finds it and manages to keep the flower, he will not be influenced by evil charms. According to people's beliefs, in order not to lose the flower you need to cut the palm of your hand and put it into the incision, where it will overgrow on its own, without any pain (Sueveriya, 2013). The plant's property is verbalized in the phytonym Schildfarn (German der Schild 'shield') (Rubtcova, 2015).

Treasure hunters throw spleenwort flower upward to search for earth riches. "If there is a treasure, this flower will fly over it like a star and fall directly to the ground" (Saharov, 1885). The ability of fern flower's owner to open hidden treasures, to see the past and future, to become invisible, happy and rich is reflected in the phytonym Glückshand literally. 'Lucky hand' (German das Glück 'happiness', die Hand 'hand') (Rubtcova, 2015).

Wormwood was not only worn in the bosom, but it was also placed on the windows and thresholds of 
houses to protect against evil spirits, especially from mermaids during the Mermaid's Week, on Ivan Kupala's day. It was also believed that if you swallow three balls of crushed wormwood leaves, you can become invisible to mermaids (Slavyanskie drevnosti, 2009). Girls wove wreaths, and also girded with them to protect themselves for a whole year from evil spirits, witchcraft and diseases (Kuznetcova, 1992). Compare: German. Johannesgürtelkraut, Gürtelkraut (German der Gürtel 'belt'; das Kraut 'herb') (Rubtcova, 2015). When people went into the depths of the forest for a magical flower during the night of Johannestag, in addition to the incense and the Easter candle, they always took wormwood branch (Dal ', 1998).

The emergence of the German phytonym Beifuss latterly. 'Near the leg, next to the leg' is associated with the popular belief that the traveler would not get tired on the road, a bunch of wormwood was tied to his leg (Duden, 2007). Compare also: German. Gewürzbeifuss, Wermutbeifuss (Rubtcova, 2015).

Elecampane is usually collected before sunrise on the eve of Ivan Kupala's day. Consecrated at nine Matins the Neunkrauft (German neun 'nine'; die Kraft 'strength') herb gives a person "nine powers". For protection from the evil spells of witches, a bag of witch herb, Hexenschusskraut (German die Hexe 'witch', der Schuss 'shot', das Kraut 'herb') was customary carried among the people (Rubtcova, 2015).

Since ancient times, Dope has been highly valued by sorcerers and magicians as a miraculous medicinal plant, and even a hallucinogen. To control the minds of people, witches added dope juice to their ointments in medieval Europe. Rubbing these ointments into their bodies, sorceresses flew to coven, met with devils (Handbuch, 2012). Compare: German: Fliegenkraut (German fliegen 'fly'), Teufelsapfel (German der Teufel 'damn'; der Apfel 'apple'), Rauschapfel (German rauschen 'cause intoxication') (Rubtcova, 2015).

Angelica begins to bloom on May 8, the day of commemoration of St. Michael the Archangel. It is believed that angelica has mystical powers, banishing diseases and evil spirits. According to legend, this herb received the Latin name Archangelica in honor of Arch. Raphael, who revealed to a local monk the mystical properties of Angelika in the $X$ century, in France, and how to heal the city from the plague with this herb (Kuznetcova, 1992). Compare: German. Angelikawurzel, Gartenengelwurz, Engelwurz (German der Engel 'angel'; die Wurz ust.dial. 'Root'), Heiligengeistwurz (German heilig 'saint'; der Geist 'spirit') (Rubtcova, 2015).

The girls drank infusion Schöngesicht literally. 'pretty face', tricolor violets for becoming beautiful, as it was believed that this plant has the magical power of turning girls into beauties. Compare also: German. Liebesgesichtli, Liebgsichtli (Rubtcova, 2015).

In the old days, it was believed that pansies, presented to a lover before a long parting, were symbolized the loyalty and love of the girl who gave it (Makkalister, 2007). Phytoonyms can also be associated with this belief. German .Denkanblümlein, Gedenkemein (German denken 'think, remember, remember') (Rubtcova, 2015).

There was a belief that the first girl, finding a primrose flower on Easter holidays, would undoubtedly marry in the same year (Kuznetcova, 1992). Compare: German. Heiratsschlüssel letters. 'Keys for marriage' (Rubtcova , 2015).

According to the old custom, the newlyweds put the herb of lungwort under the pillow for long life of the spouses and healthy children. Legend exists that the blue flowers of the lungwort are the flowers of Adam, the first man, and the pink ones are of Eve, the first woman. Two different colors on one plant symbolize the unity of opposites (Netetckaya, 2010). The following phytoonyms are associated with this belief - German. Großvater und Großmutter literally 'grandmother and grandfather', Fleisch und Blut letterlly. 'Meat and blood' (Rubtcova, 2015).

\section{CONCLUSION}

In modern language education, the distributive analysis of the German names of medicinal plants according to the principle of the nomination "folk beliefs, superstitions" clearly reveals the variability of the use of medicinal plants in human life. Medicinal plants are closely connected with otherworldly, unrealistic ideas of the people. Superstitious ideas of people give rise to legends, prohibitions, parables, in which the main amulet-a protector from evil spirits, an assistant in strengthening family relations is a plant.

The irrepressible desire to conquer nature, to know the new and unknown is reflected in the phytonyms for the nomination of plants associated with the pagan holiday of Ivan Kupala. Pagan and Christian theological ideas contributed to the fact that herbalists endowed plants with a supernatural ability to cure ailments, protect from death and injury.

"Witch herbs" occupy a special place in the field of plant application. People put them around the house, in 
the barn, ate them with only one purpose - to protect themselves, their relatives, their home and their farm from evil sorcerers. Sometimes people used the services of healers. They asked the healers to make amulets for health and protection from evil spirits the help of spells and herbs.

\section{REFERENCE LIST}

Bogdanova, N.V., Kolyago, A.L., Fokina, A.A., Sokolova, G.L., Yandakova, E.L. Nominative sentences in languages with different systems (Mari and German). Proceedings of INTCESS 20174th International Conference on Education and Social Sciences 6-8 February,2017-Istanbul, Turkey. Page No. 614-617.

Dal', V. I. (1998). Explanatory dictionary of the living Great Russian language: in 4 parts. M., 1998. - P.3:$896 \mathrm{p}$.

Duden (2007). Das Herkunftsworterbuch. Band 7. - Mannheim, 2007. - 960 S.

Handbuch (2012). Das große Handbuch der Kräuter und Heilpflanzen. - Köln, 2012. - 640 S.

Kuznezova, M.A. (1992). Kuznezova M.A., Reznikova A.S. Legends about medicinal plants. - M., 1992. 272 c.

Makkalister, R. (2007) All about plants in legends and myths. - Spb, 2007. - 192 p.

Markina, L.G. (2006) German culture: linguistic and cultural dictionary: over 5000 units- M., $2006 .-1181$ p.

Netetckaya, A.(2010) Queen of the shadow lungwort // Owner. - 2010. - № 2. - P. 19-20.

Potebnya, A.A (2000) Symbol and myth in popular culture- M., 2000. - 480 p.

Rubtcova, O.G. (2014) Motivema "Magical properties" in phytonyms of different structural languages (by the material of the Mari, Russian, German and Latin languages // Bulletin of the Chuvash University. Humanities. - Cheboksary, 2014. №1/2014. - P. 143-148.

Rubtcova, O.G. (2015) A short four-lingual dictionary of phytonyms (by the material of the Latin, Russian, Mari and German languages).- Yoshkar-Ola, 2015. - 94 p.

Saharov, I. P. (1885) Tales of the Russian people, collected by I. P. Saharov. - Spb, 1885. http://www.bibliotekar.ru/rusSaharov/index.htm

Slavyanskie drevnosti (2009). Slavic Antiquities: an ethnolinguistic dictionary: in 5 p. - M., 2009. - P.4:- 656 p.

Sokolova, G.L., Kolyago, A.L., Fokina, A.A., Rychkov, A.V., Bogdanova, N.V., Trubyanova, I.V., Yandakova, E.L. Expression of purpose in the Mari and the German languages. Proceedings of INTCESS 2017 4th International Conference on Education, Social Sciences and Humanities 10-12 July,2017 - Dubai, U.A.E. P. 240-243

Sueveriya, (2013). Superstitions and prejudices of the peasants of the Voronezh province: Chrestomathy. Voronezh, 2013. - 272 p. 